\title{
Construcción poética e ideológica del matrimonio y de la esposa en la epístola de Boscán ${ }^{1}$
}

\author{
Clara Marías Martínez \\ Universidad Complutense de Madrid \\ Westfälische Wilhems-Universität Münster \\ mariasma@uni-muenster.de
}

Recepción: 29/07/2013, Aceptación: 09/10/2013, Publicación: 20/12/2013

\section{Resumen}

Este artículo se propone revisar la visión del matrimonio y de la esposa que aparece en los célebres pasajes de la epístola poética de Juan Boscán a Diego Hurtado de Mendoza (c. 1540). Primero analiza la visión de Boscán de su esposa y su matrimonio y la conexión con su cambio poético e ideológico, teniendo en cuenta los otros poemas que forman parte de este ciclo del amor nuevo. A continuación, se compara la poesía del amor conyugal de Boscán con otros autores que han enfocado esta clase de amor: el poeta neolatino italiano Pontano, el neolatino francés Salmon, y el portugués Ferreira. Por último, se leen los versos matrimoniales del poeta barcelonés a la luz de los tratados de Vives y Castiglione, que pudieron aportarle una base conceptual para su construcción ideológica del amor conyugal.

Palabras clave

Boscán; Pontano; Salmon; Ferreira; Vives; Castiglione; epístola poética; matrimonio; esposa

\begin{abstract}
Ideological and Poetic Construction of Marriage and Wife in Boscán's Epistle

This article reexamines the depiction of marriage and the figure of the wife in the renowned passages from Juan Boscán's verse epistle to Diego Hurtado de Mendoza (c. 1540). Firstly, it analyzes Boscán's representation of his wife and their marriage and draws connections with the poetic and ideological change he underwent, with reference to other poems that constitute this cycle of new, reciprocal love in an anti-Petrarchan mode. The analysis compares Boscán's poetry of conjugal love with that of other authors who focused on this type of love: the Italian Neo-Latinist poet Pontano, the French Neo-Latinist Salmon, and the Portuguese Ferreira. Treatises by Vives and Castiglione also shed light on Boscán's matri-
\end{abstract}

1. Este artículo es una versión reducida del análisis más profundo que desarrollo en mi tesis doctoral en curso «Pensamiento clásico y experiencia autobiográfica en la epístola poé- tica del primer Renacimiento». Agradezco a mi director de tesis, Álvaro Alonso Miguel, sus correcciones y sugerencias. Sandidge (2004): 338-339. 
monial poetry, for they offer conceptual underpinnings for its ideological construction of conjugal love.

\section{Keywords}

Boscán; Pontano; Salmon; Ferreira; Vives; Castiglione; verse epistle; marriage; wife

Este artículo se propone revisar la visión del matrimonio y de la esposa que aparece en los célebres pasajes de la epístola poética de Juan Boscán a Diego Hurtado de Mendoza (c. 1540). Si bien la correspondencia entre este canto al amor conyugal y la experiencia autobiográfica del poeta barcelonés parece indudable, y la lectura en esta clave encaja con el contexto de escritura de la epístola — un recién casado ya maduro se dirige a un embajador soltero, cuyos afanes por alcanzar el matrimonio quedan reflejados en sus cartas en prosa ${ }^{2}$-, resulta también fructífero analizar la construcción poética e ideológica que Boscán lleva a cabo al abordar este tema. En primer lugar, analizaremos la visión de la esposa y del matrimonio por parte del poeta, así como la posible conexión con el cambio poético e ideológico que experimenta, teniendo en cuenta otros poemas que forman parte de este ciclo del amor nuevo, para centrarnos especialmente en la relación entre matrimonio y sexo, y entre matrimonio y renovación psicológica y poética. A continuación, compararemos la poesía del amor conyugal de Boscán con la de otros autores que han enfocado esta clase de amor: el poeta neolatino italiano Pontano y el neolatino francés Salmon, y el portugués Ferreira. Además de señalar las semejanzas y diferencias entre las visiones de los cuatro, y de analizar las referencias al amor sensual de Boscán en relación con las de Pontano, resulta interesante el hecho de que Pontano pudo ser una influencia para Boscán; mientras que Salmon escribe en las mismas décadas y de haber relación entre ambos poetas, no es fácil determinar en qué sentido sería; y Ferreira escribe posteriormente y parece tener en cuenta la obra del barcelonés. Así pues, pueden observarse los distintos eslabones de esta cadena de conexiones, imitaciones o coincidencias en la construcción poética del matrimonio y de la esposa, en la cual Boscán ocupa un lugar central. Por último, leeremos los versos matrimoniales del poeta barcelonés a la luz de los tratados de Vives y Castiglione, que pudieron aportarle una base conceptual para su construcción ideológica del amor conyugal.

2. Hurtado de Mendoza (1935). 


\section{La exaltación del matrimonio y de la esposa}

A partir del primer tercio de la epístola de Juan Boscán a Diego Hurtado de Mendoza (en el verso 130 de 404), tras señalar que ha hecho efectiva en el matrimonio la doctrina aristotélica de la "dorada medianía» poetizada por Horacio (y aclarando así que en su caso no se trataba de hipócritas declaraciones), el poeta comienza a describir los efectos positivos del mismo. Esta defensa y exaltación de la vida conyugal y de la esposa resulta, como ha señalado la crítica, una de las notas más originales de la poesía de Boscán, puesto que no se hallan paralelos en muchos autores en verso, aunque sí coincida con una corriente de pensamiento defendida por humanistas como Alberti en su Libro della famiglia, o con la de Erasmo, que destacaba el papel de la esposa para contener la lujuria del hombre. Como resumía Sandidge: «Although Luther, Calvin, Erasmus and other Renaissance theologians held beliefs inherited from patristic and medieval theologians about female lust [...] they also valued wives as useful for containing male sexual immoderation. [Erasmus said in 1519] 'What is sweeter than living with a woman with whom you are most intimately joined not merely by the bonds of affection but the physical union as well?' " ${ }^{2}$. Esta estudiosa recuerda que tanto el movimiento reformista como la corriente petrarquista fueron sustanciales en la mejora de la imagen de la mujer, así como en su valoración positiva en tanto que influencia beneficiosa para el hombre - $\mathrm{y}$ no solo origen de sus pecados-, con la diferencia de que las relaciones sexuales que dichos humanistas consideraban positivas en el seno del matrimonio, aparecían en la poesía como deseos insatisfechos. Reeser destaca que la opinión positiva de Erasmo sobre el matrimonio y su papel en las relaciones íntimas está estrechamente relacionada con su visión de la sexualidad como algo natural en el ser humano y no como un pecado ${ }^{3}$. ¿Podría estar el discurso de Boscán relacionado con estas ideas? Parece que aunque la influencia más poderosa provenga de su experiencia vital, en la formulación poética de sus ideas sobre el matrimonio se sirve, para legitimarlas, del pensamiento religioso y de la filosofía neoplatónica y la defensa de las cualidades de la mujer recogidas en los Libros III y IV de El Cortesano de Castiglione, como analizaremos más adelante. Aunque en la epístola de Boscán aparece la idea de que este nuevo amor que le inspira es casto, «agora el casto amor acude y manda/que todo se me haga muy sabroso» ${ }^{4}$, no hay el mismo peso de la religión que en los sonetos con la misma temática, pues se destaca sobre todo la dimensión pasional, lo que sí parece recordar las ideas erasmistas, más que las neoplatónicas, aunque ciertos elementos de estas últimas también aparecen. Boscán intenta conciliar la pasión amorosa con la legitimación de la misma, y para ello insiste en dos ideas. El matrimonio ha supuesto para él una renovación, un renacimiento, pues su mujer le ha mejorado como persona al apartar de él pensamientos negativos y actos que podrían ser considerados peca- 
dos. Además, el matrimonio ha supuesto la vía de expresión de su deseo amoroso y el fin de los problemas que éste le causaba al no poder satisfacerlo o al dejarse llevar por él en exceso, idea que recoge la influencia del erasmismo y la aplicación del "término medio" al amor sensual. Veamos cada una de estas dos ideas y su conexión con otros poemas de Boscán que puedan aclarar o afianzar su significado.

La idea de renovación y mejora aparece desde el principio del pasaje, pues a mi juicio así podrían interpretarse los versos 130-2: «Esta [su mujer] m’à dado luego un nuevo ser,/ con tal felicidad, que me sostiene/ llena la voluntad y el entender ${ }^{5}$. Carlos Clavería entiende que con «nuevo ser» se refiere a su hija Mariana, y ello le reafirma en fechar del poema hacia $1540^{6}$. Sin embargo, parece que en el contexto de dicha expresión, y sobre todo, si se compara con otros poemas, el «nuevo ser» podría ser sin forzar la interpretación el «nuevo Boscán» nacido de los efectos del matrimonio y del amor correspondido, que entona desde su nueva identidad un nuevo canto lleno de felicidad y armonía. En varios pasajes de la epístola aparece la celebración del amor correspondido y la mejora moral que ha supuesto para él, pues gracias al trato con su esposa ha superado el error de sus anteriores devaneos amorosos:

Esta me haze ver que'lla conviene a mí y las otras no me convenían; a ésta yo tengo y ella me tiene ${ }^{7}$ (vv.133-136)

[...]

De manera, señor, que aquel reposo que nunca alcançé yo, por mi ventura, con mi philosophar triste y pensoso, una sola muger me l'asegura, y en perfecta sazón me da en las manos vitoria general de mi tristura.

$Y$ aquellos pensamientos míos tan vanos ella los va borrando con el dedo y escrive en lugar d'ellos otros sanos/psalmos ${ }^{8}$ (vv. 166-174) [...]

Ganancia sacaré del acidente que otro tiempo mi sentir turbava, traiéndome perdido entre la gente. ¿Qué haré d'acordarme cuál estava viéndome cuál estoy, que estoy seguro

5. Boscán (1999): 364 .

6. Clavería (1999): 364 , nota al verso $128:$ El poema ha de estar escrito hacia 1540 , porque Boscán casó en 1539 con Ana Girón de Rebolledo, y en el v. 130 cita un nuevo ser: su hija Mariana».

7. Boscán (1999): 364.

8. Boscán (1999): 366. Carlos Clavería elige la variante "psalmos», la presente en la edición princeps, en su edición de Boscán (1991), mientras que en la de Boscán (1999) cambia de criterio y escoge la variante de la edición de 1875, «sanos». Por ello recojo ambas posibilidades. 
de nunca más pasar lo que pasava?

En mi fuerte 'staré dentro en mi muro, sin locura d'amor ni fantasía

que me pueda vencer con su conjuro.

Como digo 'staré en mi compañía, en todo se me hará el camino llano, su alegría mezclando con la mía.

Su mano me dará dentro en mi mano, y acudirán deleites y blanduras,

d'un sano coraçón en otro sano9 (vv. 280-294)

Compárense estas ideas con las que aparecen en los siguientes fragmentos de sonetos, todos pertenecientes al ciclo del amor correspondido y celebrado, para advertir en estos últimos el mayor peso de la religión en metáforas e imágenes:

\begin{tabular}{|l|l|}
\hline $\begin{array}{l}\text { Soneto CXIV } \\
\text { A...] canto de'amor mis bienes sosegados empieça Amor un nuevo canto }{ }^{10}\end{array}$ & $\begin{array}{l}\text { Soneto CXVI } \\
\text { que Amor me levantó de frío y } \\
\text { muerto, } \\
\text { haziéndome quedar bivo y contento. } \\
\text { El milagro fue hecho'strañamente, } \\
\text { porque resucitando el mortal velo, } \\
\text { resucitó también la inmortal alma. } \\
\text { Celebrado seré en toda la gente, } \\
\text { llevando en mi triumpho para'l cielo, } \\
\text { con el verde laurel la blanca palma. }\end{array}$ \\
\hline $\begin{array}{l}\text { Soneto CXVII } \\
\begin{array}{l}\text { Demás del gran milagro que Amor hizo, } \\
\text { haziéndome, después de'star deshecho, } \\
\text { fue muy maravilloso y nuevo hecho } \\
\text { ver que un Amor me hizo y me deshizo }\end{array}\end{array}$ & $\begin{array}{l}\text { Soneto CXVIII } \\
\text { Unuevo Amor un nuevo bien m'ha } \\
\text { illustrándome'l alma y el sentido. }\end{array}$ \\
\hline $\begin{array}{l}\text { Soneto CXX } \\
\text { hasta que Dios con su absoluto mando } \\
\text { mi guerra convirtió en tanta vitoria, } \\
\text { que agora vencedor estoy triumphando, } \\
\text { dexando'scrita en todos larga istoria }{ }^{14}\end{array}$ & $\begin{array}{l}\text { Como en el mar, después de la } \\
\text { tiniebla, } \\
\text { pone alboroço el asomar del día, } \\
\text { y entonces fue plazer la noche'scura, } \\
\text { así en mi corazón, ida la niebla. }\end{array}$ \\
\hline
\end{tabular}

9. Boscán (1999): 370 .

10. Boscán (1999): 226. La negrita en todas las citas del artículo es mía.

11. Boscán (1999): 227.
12. Boscán (1999): 228.

13. Boscán (1999): 229.

14. Boscán (1999): 230.

15. Boscán (1999): 232. 


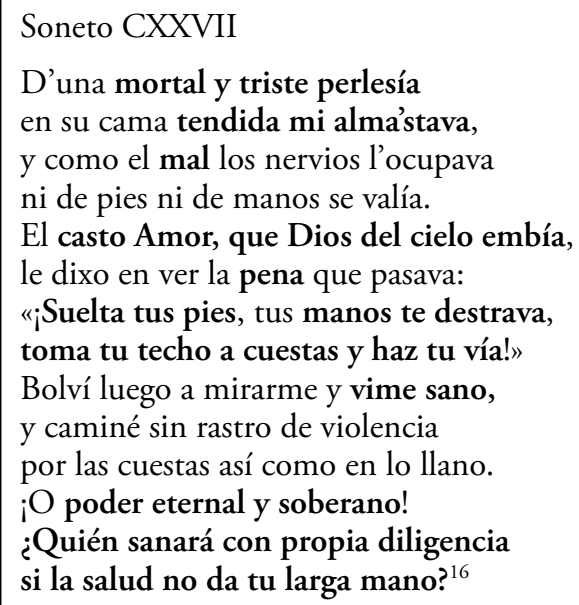

La intervención divina (ya sea, en determinadas ocasiones, de la divinidad pagana Amor, en otras, del Dios cristiano, o bien, de una fusión de ambos) resulta indispensable en los sonetos para la mejora moral y vital del poeta, y del mismo modo sucede en la Canción CXXX, donde el sujeto lírico resume su evolución desde los amores mundanos y lascivos, en los que creía equivocadamente hallar la felicidad, hasta que Dios le sacó de su error, mostrándole la verdad que no quería escuchar de boca de sus buenos amigos:

\footnotetext{
Si algún prudente amigo me dezía "estos bienes d'Amor no permanecen", por pesada sentencia la juzgava.

Ninguna forma de desdicha hallava que'mbaraçar pudiese mis venturas. ni vacilavan ya mis esperanças con escuchar mudanças de mugeres que han hecho ya locuras [...]

Resucitado pues d'aquella muerte que mató bivamente mis sentidos, los de l'alma y también los corporales. bolviendo atrás, mis ańos vi perdidos y vi que fui caído en baja suerte, igual con los más bajos animales ${ }^{17}$ (vv. 34-41 y vv. 76-81)
}

En la epístola encontramos el mismo despertar y el mismo reconocimiento de los errores pasados, así como idéntico deseo de mostrar a los demás lo que 
ha aprendido, pero ha desaparecido la dimensión religiosa de los sonetos y de la canción, pues la propia metamorfosis está atribuida al efecto benéfico de la esposa más que al del «casto Amor» mensajero de Dios, y tampoco se presenta en términos religiosos, como un milagro, o como la resurrección de Lázaro. Por ello tampoco hay la misma necesidad de extender el mensaje divino, que en la canción CXXX tiene un peso nada desdeńable: «Y este contentamiento es tan fundado, / que aun andaré, por todos, predicando / que, amando o desamando, / se den priesa a llegar do yo é llegado ${ }^{18}$. Todos los poemas comparten la misma dimensión de renacimiento y de aprendizaje, y el mismo contraste entre amores pasados, superfluos, mudables (dictados por la Venus Pandémica, según El Banquete de Platón) y el amor presente, estable y con efectos positivos sobre el amante (bajo la égida de la Venus Uránica esta vez, aunque aplicado al amor heterosexual en lugar de al homosexual). Pero en la epístola hay una insistencia mucho mayor en el poder de la esposa que en la intervención divina, así como en la dimensión humana más que en la sobrenatural, y a su vez en el cambio psicológico más que en el religioso-moral. Buena prueba de ello es que la «vitoria» que en el soneto CXX se atribuía a Dios, en la epístola la entrega la mujer. La influencia de la esposa es aún mayor en tanto que, tras borrarle con el dedo los antiguos pensamientos "vanos» (en el sentido de 'sensuales', como muestra el empleo del mismo término cuando se niega a describir los placeres de su matrimonio: «lo que d'este tiempo a la mañana / pasare, pase agora sin contarse / no cura mi pluma de ser vana» ${ }^{19}$ ), le escribe otros $«$ sanos $»^{20}$ en su lugar. El poeta, con la idea de que su esposa le escribe "pensamientos sanos», reconoce que los "trabajos de amor disperso» ${ }^{21}$ le enfermaban. Pero aún así, el interés sigue centrándose en el amor humano y en su dimensión más corporal. Se emplean a tal efecto ideas e imágenes propias del estoicismo, como la liberación de la esperanza o del miedo (que recuerda la ataraxia y estabilidad del sabio, salvaguardada gracias al control de las pasiones), o bien se recurre a la escritura, borrado y reescritura de los pensamientos (que recuerda la concepción estoica del alma como una tabla de cera en la que lo exterior imprime sus signos), pero en un contexto que subvierte su sentido. Lo esencial de este pasaje es el protagonismo de la esposa y su capacidad para transformar al sujeto poético, para

18. Boscán (1999): 237-241

19. Boscán (1999): 372.

20. Recordemos que la lección que ofrece la princeps de 1543, «psalmos», respetada por C. Clavería en su edición de 1991, es enmendada en 1875 por W.I. Knapp, que prefiere «sanos», variante que respeta la sintaxis y la rima consonante del terceto, y por ello es incorporada por Clavería en 1999. El asunto no es baladí, ya que la versión de la princeps rompe con la rima en "-anos» («manos», "vanos», "psalmos») y cambia el sentido del pasaje.

21. Nada más acertado para describirlos que esta paráfrasis de Shakespeare que hizo Jaime Gil de Biedma en su poema «Pandémica y Celeste», donde, como Boscán, comparaba ambas clases de amor: «aunque sepa que de nada me valdrían/trabajos de amor disperso/si no existiese el verdadero amor/Mi amor/Íntegra imagen de mi vida». Gil de Biedma (2006): 178. 
cambiar su manera de pensar. La mujer actúa como escritora, borra las ideas de su marido y escribe las propias. Estos versos pueden leerse en clave metapoética: los pensamientos «sanos» serían los poemas que le inspira, es decir, los sonetos y la canción comentados anteriormente, además del poema que nos ocupa. Se refuerza esta interpretación si atendemos al comienzo de la epístola, donde Boscán también parece expresar la dificultad de encarar esta nueva vertiente de su poesía. Podemos comparar la evolución poética del Libro III de Boscán con la del Canzoniere de Petrarca: coinciden en el reconocimiento de los errores pasados y en el propósito de enmienda, pero tanto el punto de partida como el de llegada son muy distintos, pues Petrarca evoluciona desde el amor humano, inspirado por la mujer, al amor divino; en cambio, Boscán cambia los amores plurales y transitorios de las amadas por el amor estable de la esposa; pero todos ellos son humanos, aunque el segundo tenga ciertas connotaciones religiosas al encuadrarse en el matrimonio. La epístola supone en este sentido una renovación formal, al imitar modelos genéricos clásicos ausentes en la poesía vernácula de Petrarca, y una renovación temática, al incluirse en el ciclo del amor correspondido y celebrado, que si bien tenía una relevante tradición en la poesía neolatina - véase Pontano-, no se había frecuentado en lengua vul$\operatorname{gar}^{22}$. Esta composición constituiría parte, así, del intento de Boscán de superar la poesía petrarquista o de dar nuevos aires y contenidos a su poesía, ensayo paralelo al de Garcilaso de la Vega, aunque en su caso parece que inspirado por circunstancias más vitales que poéticas —es decir, más por querer incluir en su poesía sus nuevas experiencias que por imitar otros modelos distintos a los de Petrarca y Bembo, como el de los neolatinos o el anti-petrarquista de Bernardo Tasso, quien además de adaptar los géneros clásicos también incorporó el amor conyugal a sus versos ${ }^{23}$. El valor de este intento poético y la novedad del amor feliz de Boscán quedan de manifiesto en el ciclo de sonetos que dedica a su muerte el poeta napolitano Luigi Tansillo (1510-1568), y en el que le dedica a su esposa, ya viuda:

22. En la península aparecen sobre todo en el ámbito de la Corona de Aragón, como Hugo de Urríes, Jaume Roig (L'espill) y Romeu Llull en el s. xv. En Italia, en lengua vernácula, destaca especialmente el poeta napolitano Berardino Rota (1508-1575), que dedica un ciclo de sonetos a la muerte de su esposa, pero es posterior a Bos- cán (1559), ejemplos anteriores o coetáneos a Boscán serían el Panormitano (s. Xv), Bernardo Tasso, Vittoria Colonna, y Luigi Tansillo.

23. Bernardo Tasso, como luego Rota, dedica varios sonetos al lamento por la muerte de su esposa Porzia (en las Rime, el soneto 4 del libro IV, y los sonetos 136 y 153 del libro V, por ejemplo). 


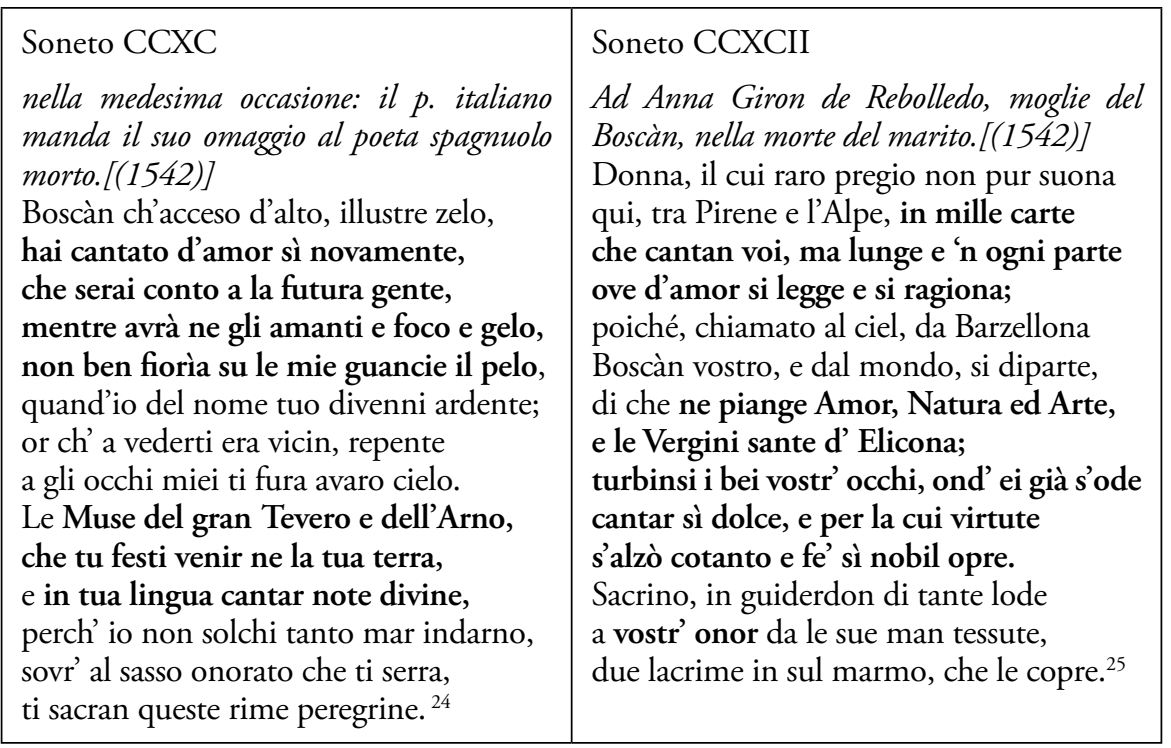

Del soneto que dirige a Boscán, destaca especialmente la idea de Tansillo de que el barcelonés ha cantado al amor de manera novedosa, frente a la metáfora petrarquista de los amantes atrapados entre el fuego y el hielo. La relación del matrimonio de Boscán con esta renovación poética queda aún más de manifiesto en el soneto que el napolitano dedica a Ana Girón de Rebolledo, ya viuda, en tanto que celebra su fama: «in mille carte che cantan voi» muestra la difusión de la poesía conyugal de Boscán entre los Pirineos y los Alpes, en un momento de intensos debates sobre la naturaleza del amor y sobre el matrimonio.

\section{La construcción poética del matrimonio: Boscán frente a Pontano, Salmon y Ferreira}

A pesar de este intento de apartamiento del petrarquismo y bembismo que vemos en la epístola, y a pesar de que en ella lo espiritual no tiene el mismo peso que los sonetos y la canción del ciclo del amor correspondido y celebrado, sí aparece en ella una huella del neoplatonismo defendido por Bembo: «Su mano me dará dentro en mi mano/y acudirán deleytes y blanduras,/d'un sano coraçón en otro sano» (vv. 292-4) parece recordar al pasaje de El cortesano en que se describe el intercambio de almas del amor casto propio de la madurez. En este sentido, parece que Boscán tiene muy presente el modelo descrito por Bembo, puesto que la perspectiva de la epístola coincide perfectamente con la evolución desde los amo- 
res sensuales (que Bembo trata de viciosos, enemigos de la razón y placeres de las bestias), comprensibles y hasta disculpables en la juventud, al amor más racional y elevado propio de la vejez. En otros sonetos y en la canción hay más paralelismos con los capítulos VI y VII del Libro II de El Cortesano, por ejemplo, en la descripción de la ceguera que le hacía pensar que sus amores pasados eran fuente de placer, y en la idea del amor humano como elevación hacia la virtud y hacia Dios. Sin embargo, Boscán no abraza en la epístola los presupuestos del neoplatonismo, puesto que sigue exaltando la unión de los cuerpos, no solo la de las almas.

Cierto es que su celebración no es tan abierta y claramente sexual como la de los poemas neolatinos — que pudo conocer $^{26}$ - de Giovanni Pontano (14261503), quien describe la unión corporal y la desnudez de la mujer no solo en sus poemas a las jóvenes de los baños, sino también en los dedicados a su esposa Ariane Sassone, en los que destaca que además de ser la alegría de su madurez — se casó con ella en 1461, con treinta y cinco años- también le ha rejuvenecido al despertar en él de nuevo la pasión. La situación descrita por Boscán coincide con esta visión en la celebración del amor maduro, y de la vitalidad que proporciona, pero donde Pontano introduce referencias directas y descripciones detalladas del cuerpo femenino, el poeta barcelonés solo se atreve a mencionar una sola vez su ansiedad por la unión amorosa, dejando lo demás entre líneas. La diferencia de tono e intensidad hacen que el «atrevimiento» de Boscán palidezca ante el del poeta neolatino, pero ello no le resta valor, pues hay que tener en cuenta la difusión más restringida de la poesía neolatina entre lectores de mayor formación, lo que a su vez podía favorecer una mayor libertad en el tratamiento de los temas. Compárense los siguientes fragmentos para advertir la diferencia de tono y de intensidad, así como la mayor sensualidad de la poesía conyugal de Pontano:

26. Los poemas de Baiae fueron escritos entre 1490-1500, cuando Pontano tenía entre 64 y 74 ańos, y publicados al menos, según las ediciones censadas en EDIT 16, en $1505,1513,1518,1520$ y 1533 . Numerosas ediciones se encuentran en el CCPB y pudieron difundirse por la península antes de 1550 . 


\begin{tabular}{|c|c|}
\hline $\begin{array}{l}\text { Uxorem ac liberos invitat ad diem } \\
\text { natalem celebrandum } \\
\text { coniux, requies senis mariti }{ }^{27} \\
\text { Ad Ariadnam uxorem } \\
\text { Uxor, deliciae senis mariti } \\
\text { et casti thalami fides amorque, } \\
\text { per te vel viridis mihi senecta est, } \\
\text { quem curae fugiunt senem seniles, } \\
\text { qui seram supero senex senectam } \\
\text { et canus iuvenum cano furores; } \\
\text { sed tanquam redeat calor iuventae } \\
\text { et sis cura recens amorque primus } \\
\text { et primus furor impetusque saevus, } \\
\text { antiquas volo suscitare flammas }[. .] \\
\text { suspirans viduo puella lecto, } \\
\text { fulgebas mihi primulosque amores } \\
\text { spirabas oculis sinuque blando } \\
\text { afflabas Arabum suos odores }{ }^{28}[. . .] \\
\text { procedit thalamo novosque amores } \\
\text { et novas parat excitare flammas: } \\
\text { spirant omnia, quae reflectit ora [...] } \\
\text { et spargis veneres cupidinesque: } \\
\text { rident omnia et aerem serenas }{ }^{29}[. . .] \\
\text { mox cursans Amor huc et huc et illuc } \\
\text { et per guttura, per genas manusque } \\
\text { et per collaque lucidamque frontem, } \\
\text { et per pectora candidosque dentis, } \\
\text { ut iam non Amor is, sed ignis esset, } \\
\text { qui seram quoque calfacit senectam }{ }^{30}\end{array}$ & $\begin{array}{l}\text { Epístola de Boscán } \\
\text { Agora el bien es para gozarse, } \\
\text { Y el placer es lo que es, que siempre place, } \\
\text { Y el mal ya con el bien no ha de juntarse. } \\
\text { Al satisfecho todo satisfaze, } \\
\text { Y assí también a mí por lo que é hecho } \\
\text { Cuanto quiero y deseo se me haze. } \\
\text { El campo que era de batalla, el lecho, } \\
\text { Ya es lecho para mí de paz durable: } \\
\text { Dos almas hay conformes en un pecho }{ }^{31} \\
\text { [...] } \\
\text { Ya estoy pensando, 'stando en mi posada, } \\
\text { Cómo podré con mi muger holgarme, } \\
\text { Teniéndola en la cama o levantada. } \\
\text { [...] } \\
\text { Tenderme ha allí la halda de su saya, } \\
\text { Y en regalos de amor habrá porfía, } \\
\text { Cuál de entrambos hará más alta raya. } \\
\text { El río correrá por do es su vía, } \\
\text { Nosotros correremos por la nuestra, } \\
\text { Sin pensar en la noche ni en el día. }{ }^{33} \\
\text { [...] } \\
\text { pasaremos la noche dulcemente, } \\
\text { Hasta venir el tiempo que la gana } \\
\text { De dormir toma al hombre comúnmente. } \\
\text { Lo que de 'ste tiempo a la mańana } \\
\text { Pasare, pase agora sin contarse, } \\
\text { Pues no cura mi pluma de ser vana. } \\
\text { Basta saber que dos que tanto amarse } \\
\text { Pudieron, no podrán hallar momento } \\
\text { En que puedan dexar siempre d'holgarse. } \\
\text { a4 }\end{array}$ \\
\hline
\end{tabular}

27. Pontano (2006): 34-38. Poema 12, v. 3. "Wife, who are an old husband's repose».

28. Pontano (2006): 38-39. Poema 13, vv. 1-10 y 21-25. Reproduzco la traducción inglesa a falta de la española: "Wife, your elderly husband's delight,/love and trust of our chaste bed,/You who keep my old age fresh,/who set an old man's cares to flight,/and help my triumph over old age,/a grey head singing of youthful passion;/But, as if fires of youth return/and you were at once first love and new,/ first passion, headlong rush,/I want to fan those ancient flames", "A girl sights in an empty bed,/you gleam at me and from your eyes/emit love's dawning rays/and from your soft, sweet breasts/exhale Arabian fragances».
29. Pontano (2006): 40-41. Poema 13, vv. 30$34 \mathrm{y}$ vv. 54-55. "She enters the chamber and prepares/to stir to life new loves and flames/ all things breathe when she turns her face/All things shine where she turns her face», "You scatter love and hot desire;/all things laugh, you clear the air".

30. Pontano (2006): 42. "Presently Love ran here and here,/over your throat and cheeks and hands,/over your neck and lucid brow,/over your shining teeth, your breast,/till it wasn't Love, but fire,/warming my declining years».

31. Boscán (1999): 365.

32. Boscán (1999): 366.

33. Boscán (1999): 369.

34. Boscán (1999): 372. 
Boscán, como Pontano, parece legitimar la pasión hacia su mujer con la alusión al matrimonio. Así, si el poeta italiano, antes de detenerse en los juegos amorosos de la pareja, describía el espacio de los mismos como "casta cama", el barcelonés alude por su parte al "casto amor», que convierte en gozoso todo lo que antes era abominable y venenoso. Pontano insiste más en que la juventud de su esposa le ha renovado la fuerza y la vitalidad perdidas, aunque también en sus poemas reconoce el poder balsámico de la mujer; en cualquier caso, el cambio psicológico no tiene tanto peso como en la poesía de Boscán. El neolatino incide más, pues, en la función rejuvenecedora del amor de una muchacha, y el poeta catalán en la función renovadora y tranquilizadora de la esposa; de ahí que Pontano describa más el cuerpo de la mujer y los sentimientos y emociones que despierta en él (tan fuertes que acaban siendo más fuego que amor), y Boscán se centre más en la narración de todas las actividades cotidianas que comparten o compartirán. Para el primero, la mujer se presenta más como objeto del deseo; para el segundo, esta dimensión aparece pero adquiere más relevancia la mujer como compañera. La celebración del amor matrimonial es sobre todo exaltación de la mujer y su belleza en Pontano, mientras que en Boscán, lo verdaderamente importante es la felicidad que se deriva de satisfacer su deseo tantas veces como quiera en el contexto de la correspondencia incondicional y la compañía cotidiana. En este sentido, aunque no sea tan sensual como Pontano, Boscán sí es muy explícito al resaltar la relevancia de la unión física como reflejo de la intensidad del amor matrimonial. Los versos «cuanto quiero y deseo se me haze./ El campo que era de batalla el lecho/ ya es lecho para mí de paz durable» ${ }^{35}$, «[...] cómo podré con mi muger holgarme,/ teniéndola en la cama o levantada ${ }^{36}$, «Y en regalos de amor habrá porfía,/ cuál de entrambos hará más alta raya ${ }^{37} \mathrm{y}$ «dos que tanto amarse/ pudieron, no podrán hallar momento/ en que puedan dexar siempre d'holgarse ${ }^{38}$ parecen referirse a la unión sexual de manera inequívoca, y no resultan tan frecuentes en la poesía castellana no explícitamente erótica de la primera mitad del xvi; menos aún en la poesía amorosa cancioneril y petrarquista. De hecho, la referencia a la imagen petrarquista «duro campo di battaglia il letto", imitada por Garcilaso en su soneto XVII, podría tratarse no de un homenaje al maestro italiano, sino de una muestra más de independencia frente al petrarquismo. Boscán contrasta, una vez más, su agitada vida amorosa pasada con la tranquilidad del presente, y para describir aquella que ahora ha superado emplea la imagen petrarquista, pero lo hace a través de la adaptación garcilasiana: 


\begin{tabular}{|c|c|}
\hline Soneto CCXXVI de Francesco Petrarca & Soneto XVII de Garcilaso de la Vega \\
\hline $\begin{array}{l}\text { Passer mai solitario in alcun tetto } \\
\text { non fu quant' io, né fera in alcun bosco, } \\
\text { ch' i' non veggio 'l bel viso, et non } \\
\text { conosco } \\
\text { altro sol, né quest' occhi ànn' altro } \\
\text { obiecto. } \\
\text { Lagrimar sempre è 'l mio sommo diletto, } \\
\text { il rider doglia, il cibo assentio et tòsco, } \\
\text { la notte affanno, e 'l ciel seren m' è fosco, } \\
\text { et duro campo di battaglia il letto. } \\
\text { Il sonno è veramente qual uom dice, } \\
\text { parente de la morte, e 'l cor sottragge } \\
\text { a quel dolce penser che 'n vita il tene. } \\
\text { Solo al mondo paese almo, felice, } \\
\text { verdi rive fiorite, ombrose piagge, } \\
\text { voi possedete, et io piango, il mio bene. }\end{array}$ & $\begin{array}{l}\text { Pensando qu'el camino iba derecho, } \\
\text { vine a parar en tanta desventura } \\
\text { que imaginar no puedo, aun con locura, } \\
\text { algo de que 'sté un rato satisfecho: } \\
\text { el ancho campo me parece estrecho, } \\
\text { la noche clara para mí es escura, } \\
\text { la dulce compañía amarga y dura, } \\
\text { y duro campo de batalla el lecho. } \\
\text { Del sueńo, si hay alguno, aquella parte } \\
\text { sola qu'es ser imagen de la muerte } \\
\text { se aviene con el alma fatigada. } \\
\text { En fin que, como quiera, 'stoy de arte } \\
\text { que juzgo ya por hora menos fuerte, } \\
\text { aunque en ella me vi, la que es pasada. }{ }^{40}\end{array}$ \\
\hline
\end{tabular}

Frente a las noches intranquilas del amante desgraciado, opone Boscán sus noches felices de hombre casado. Y con esta referencia intertextual, parece expresar a la vez el apartamiento del amor infructuoso y torturado de Petrarca y Garcilaso, y la superación de toda la poesía que se centraba en él. Podría entenderse, pues, que la introducción de este verso de raigambre petrarquista en la epístola es una muestra más del intento de renovación del poeta barcelonés. Es un ejemplo de que el poeta ha superado esta concepción del amor torturado, y ha iniciado el análisis del amor no solo desde sus efectos psicológicos y sentimentales sino también desde sus implicaciones en el comportamiento moral y en la búsqueda de la felicidad y la virtud.

Volviendo a la búsqueda de otros poemas cuya construcción del amor conyugal sea similar a la de Boscán, los versos explícitos sobre la faceta sensual del matrimonio que aparecen en la epístola no resultan tampoco muy frecuentes en el contexto más esperable, el de los epitalamios - cuyo modelo italiano es Poliziano y su Stanze per la Giostra-, que suelen celebrar el matrimonio desde una perspectiva más mitológica, religiosa o política, sin detenerse en las intimidades de la pareja. Especialmente significativa es la comparación con algunos de los más personales y autobiográficos, como los epitalamios (1528-31) del poeta neolatino francés Jean Salmon Macrin (1490-1557), coetáneo de Boscán y conocido como el «Horacio francés». $\mathrm{Ni}$ siquiera en ellos encontramos declaraciones de esta clase. En el epitala- 
mio III, «Ad Gelonidem» ${ }^{41}$, Salmon describe a su joven esposa como «épouse inséparable et compagne de ma couche», y al amor que le ofrece como «ma nourriture et mon repos» ${ }^{42}$, pero al describir la relación entre ambos recurre a imágenes petrarquistas:

si chaude est la flamme que'alluma cet enfant cruel [...] que si je désirais brûler avec plus d'ardeur et de constance et t'aimer encore davantage, je m'épuiserais misérablement dans ce souhait insensé sans pouvoir cependant atteindre le but de mon désir. ${ }^{43}$

Este poeta exalta el amor matrimonial, como Boscán, pero en la mayoría de los poemas dedicados a su esposa mantiene la actitud del amante petrarquista, hechizado por sus encantos y atormentado por la pasión. Así, en la Oda I, 24, también dirigida a su esposa, Salmon compara a Gelonis con Venus y Circe, e insiste en la imagen del amor como magia y veneno, como fuerza destructiva: «quel est le philtre dont à l'improviste tu viens de m'enivrer, au point qu' éperdu et fou d'un aveugle amour, sans être vraiment mort ni vif, je survis dans de longues tortures [...] Quel pouvoir, quelle drogue t'assistant, je ne le sais, ni quels astres si bénéfiques t'obéissent [...] peu à peu je me meurs dans de muets tourments, c'est que je suis brûlé par une flamme pernicieuse» ${ }^{44}$. De hecho, esta visión opuesta a la de Boscán en su ciclo pre-matrimonial se refuerza en la Oda II, 6, dirigida a sus amigos. En ella, Salmon narra una evolución psicológica y moral provocada por el amor que es contraria a la de Boscán, pues en lugar de presentarse como un antiguo amante ahora reconducido moralmente, se muestra como alguien que antes estaba libre de ataduras pasionales y ahora es prisionero del amor: «je suis contraint, après le coupable abandon de/ma règle de vie passée, à porter le joug de Vénus» ${ }^{45}$. Especialmente significativo es el hecho de que si Boscán dice haber alcanzado mediante el matrimonio el término medio y una postura filosófica moderada, Salmon parece haberlos abandonado por el efecto del amor de la joven Gelonis; es decir, ambos coinciden en su perspectiva moral y filosófica —adaptar ciertas ideas clásicas y acomodarlas al cristianismo- pero difieren respecto a la influencia del matrimonio sobre ellas:

41. Para mayor comodidad en la comparación, cito la traducción francesa - y no la versión latina- de la edición más reciente de Jean Salmon Macrin (2008): 155. La primera edición de los Epitalamios es la de París, G. Morrhii, 1531. No tengo datos sobre su recepción en la península ni el posible conocimiento de Boscán de la poesía de Salmon, pero por las fechas de publicación sería posible que hubiera tenido acceso al menos a los Epitalamios, que aparecen en el CCPB.

42. Salmon (1998): 155. Epitalamio III. «Ad Gelonidem».

43. Salmon (1998): 155. Epitalamio III.

44. Salmon (1998): 341. Oda I, 24. "Ad Gelonidem».

45. Salmon (1998): 413. Oda C. II. 6. «Ad Sodales". 
Autrefois, après avoir recherché les raisons des choses depuis leur origine première, entre les doctrines et les écoles de tant de philosophes divergents, je gardais par prudence la voie moyenne : j'adoptais certaines idées, j'en critiquais d'autres en dissonance avec les lois chrétiennes dont je voulais faire le principe régulateur de l'oeuvre que je m'étais assignée.

Me voici détourné de si paisibles loisirs, sans méconnaître hélas! ma disgrâce ni ignorer qu’au lieu de tranquillité des soucis de toute nature me restent! Mais quoi! Cupidon l'ordonne ainsi et je n'y peux rien. Qui oserait résister, et, en un vain effort, brandir des armes inutiles contre l'enfant et la mère de l'enfant. ${ }^{46}$

Salmon se presenta a sí mismo como impotente ante el dios Amor, que tiene un efecto desestabilizador en su vida, pues causa más sufrimiento que contento, y le hace estar dispuesto a cualquier cosa por recobrar su estado pasado: «je passerai à travers les feux cruels/au milieu de la mer, à condition que j'aie l'espoir de/retrouver la santé et la vie qui me plaisait» ${ }^{47}$. La escenificación de su infortunio amoroso parece previo a su matrimonio, pues se cierra con una petición al amigo que le presentó a Gelonis de que acabe con su sufrimiento, puesto que es el culpable del mismo.

Más semejante a la postura de Boscán es la que aparece en la Oda III, 20, dirigida de nuevo a la propia Gelonis, donde tras dibujar un locus amoenus otoñal, señala, como el poeta barcelonés en su epístola, que cualquier lugar, urbano o campestre, será maravilloso en compañía de su amada, y que gracias a ella olvidará los sufrimientos pasados. Coincide también con Boscán en la aparición de las ninfas, la invitación a los amigos, la idea de retirarse del mundo, la función calmante de la mujer, y el contraste entre la felicidad alcanzada con ella y el sufrimiento causado por los amores en el pasado. Pero además, hay otros elementos que coinciden con la epístola de Diego Hurtado de Mendoza a Boscán, principalmente la participación del sujeto lírico en las tareas campestres, la imagen de la mujer rodeada de flores y frutos ofreciéndole su amor, y el que la compañía de ella sea una fantasía, un sueño consolatorio, algo que Salmon recalca especialmente con la proyección del poeta como paseante solitario por las sombras de los bosques silenciosos, imagen muy horaciana que no suele aparecer en las epístolas hispánicas.

C'est avec toi, Gélonis, que je voudrais surtout passer ces jours, qu'il nous plaise, oisifs, de goûter les agréments de la ville, ou que nous préférions la campagne et les humbles maisons des champs. Là-bas, joyeux de participer un peu aux travaux des paysans, je ne fuirais aucune tâche [...] Je m'abandonnerais, lumière de mes yeux, au 
bonheur de m'étendre avec toi dans un vallon retiré ;

sur la lyre éolienne, je conterais les peines et les amours d'antan.

Tes baisers brûlants me plongeraient dans la

béatitud, tandis que, tressant pour toi des couronnes

de roses parfumées [...]

Ces peines atroces, toi seule peux les alléger,

même absente, car, chaque fois qu'il me souvient de

toi, dans mon âme ballotée, l'agitation se calme.

Aussi, sachant où chercher secours, je m'écarte souvent de la cour pour ne penser qu'á toi, promeneur

solitaire sous l'ombrage des forêts silencieuses. ${ }^{48}$

¿Podría haber alguna conexión directa entre la oda de Macrin y las dos epístolas? El libro III de las Odas de Macrin se imprimió con las elegías y epigramas en Paris, por Augereau en 1534, y con poemas de Du Bellay en 1546, por lo que difícilmente el poeta francés pudo haber leído las epístolas de Boscán y Hurtado, siquiera manuscritas, antes de la composición de su propio poema, a no ser que estas estén erróneamente fechadas y sean anteriores. Aunque la coincidencia de imágenes e ideas apunte hacia una relación directa, por ahora no podemos probarla. Pero resulta muy llamativo que, frente a otros poemas en los que se retrataba la figura de Gelonis con los pinceles petrarquistas, en esta oda aparece una imagen muy positiva de la mujer, asociada a la calma y a la tranquilidad, como asimismo sucede en Boscán. También parece demasiado similar la flexibilidad espacial, al no importar tanto el lugar para alcanzar un estado mental de felicidad y reposo, como la compañía de la amada. Las conexiones con la epístola de Hurtado de Mendoza parecen apuntar aún más a una relación, tanto el hecho de que el poeta se dirija directamente a la amada y le exprese sus deseos y fantasías, como el que el contenido de las mismas tenga correspondencias tan claras como la imagen de la mujer trenzando coronas de rosas, que aparecía en Hurtado de Mendoza: «el verde arrayán tuerce en derredor/de tu sagrada frente con las flores ${ }^{49}$. Quizá la influencia se produjera a la inversa, y Hurtado y Boscán leyeran las odas y epitalamios de amor conyugal de Salmon, y cada uno prestara atención a ciertos elementos. La tercera opción es que los tres poetas contaran con una fuente común que explicara estos paralelismos, posibilidad que merece una exploración más profunda en otro lugar.

En quien sin duda tuvo influencia directa la poesía del amor correspondido de Boscán fue en el renovador de la lírica portuguesa António Ferreira (1528-1569), que destaca por tener un corpus de poemas de amor feliz de igual importancia. Como señaló Thomas F. Earle, los sonetos 33-41 del libro I de sus Poemas lusitanos celebran un "amor nuevo», y presentan muchas co-

48. Salmon (1998): 575, 577. Oda III, 20. «Ad Gelonidem».

49. Hurtado de Mendoza (2007): 185. 
nexiones con los de Boscán ${ }^{50}$. La correspondencia verbal e ideológica con Boscán apunta a una relación directa, posible por la difusión manuscrita de la poesía de Garcilaso y Boscán entre los poetas portugueses, que supuso una temprana influencia, y porque además los de Ferreira debieron de ser compuestos después de 1550 - parece que su esposa murió en 1557-, es decir, cuando los versos del barcelonés ya contaban con una cuantiosa difusión impresa en España, Italia, Francia y Flandes. Así expresa Ferreira, con palabras muy semejantes a las de Boscán, su cambio poético propiciado por el amoroso: «muda esta minha noite em dia claro./Levantarei em teu nome alegre canto" ${ }^{51}$, «verdadeiro, puro, casto e santo/amor cantando vou ${ }^{52}$. Si bien el matrimonio de Ferreira con Maria Pimentel se diferencia del de Boscán por no ser de madurez — circunstancia que el barcelonés sí compartía con Pontano--, ambos tienen en común la brevedad de los mismos, ya que la esposa de Ferreira murió a los dos años de casarse, hecho que dio lugar a otro ciclo de poemas, los sonetos 1-13 del Libro II y la elegía en respuesta a la consolatoria de Pero de Andrade Caminha ${ }^{53}$. Si el amor nuevo cantado en los sonetos presenta muchas semejanzas, es especialmente llamativa la descripción del amor correspondido que realiza Ferreira en su epístola al poeta Sá de Miranda, pues en ella imagina su retiro al monte junto a su esposa, de modo similar al que narra Boscán en su epístola a Hurtado de Mendoza:

A alma de maus desejos apartando, nela, e na terra sas raízes plante, que vao fermoso fruito levantando. A ti, Marília, a ti, e às Musas cante. Alli, meu todo, e teu; livre e seguro, nada me ofenda, nada turve ou espante.

En mim metido, e forte em meu bom muro, nem o exemplo do mau me mude ou dane, nem me deja do povo o riso duro. ${ }^{54}$ (vv. 187-195)

Ferréira recoge la imagen de la transformación moral por efecto del amor correspondido, «en mi fuerte estaré dentro en mi muro/sin locura de amor ni fantasía " ${ }^{55}$, y la desarrolla en términos más estoicos, en coherencia con el resto de su poesía, en la que la vena filosófica es mucho más profunda y abundante que en el poeta barcelonés ${ }^{56}$. Pero ambos, en estos pasajes epistolares, expresan

50. Earle (1986): 233. Agradezco al Prof. Earle sus sugerencias e indicaciones respecto a los poetas portugueses durante mi estancia en la University of Oxford en 2009.

51. Ferreira (2008): 65. Soneto 34.

52. Ferreira (2008): 66. Soneto 35.

53. Esta veta de la poesía matrimonial, que podríamos llamar la "poesía de viudedad", que incluye la lamentación por la muerte de la esposa y los consuelos de los amigos poetas, la encontramos también en Pontano, en Colonna, y en Rota, como versión conyugal del Canzoniere in morte de Laura de Petrarca.

54. Ferreira (2008): 357.

55. Boscán (1999): 370.

56. Earle (1988) y (2008). 
el mismo deseo de retirarse con su esposa, e insisten en la función de la misma como musa de su nueva poesía y como estabilizadora del ánimo. Además, Ferreira parece haber leído y aprendido de la correspondencia completa entre Hurtado de Mendoza y Boscán, puesto que en su epístola a Sá de Miranda emplea la misma técnica que Hurtado al dirigirse a Boscán, cuando interrumpe la comunicación con el destinatario, para apostrofar directamente a su amada.

\section{La construcción ideológica del matrimonio: Boscán frente a Vives y Castiglione}

Como hemos visto, la descripción de la felicidad matrimonial de Boscán no tiene muchos paralelos en la poesía vernácula, y ni siquiera coincide en tono y perspectiva con los poetas neolatinos más famosos por haber exaltado el matrimonio. Si es difícil, por tanto, trazar la genealogía del tema del matrimonio para determinar qué fuentes poéticas pudieron haber ayudado a Boscán a verter estas ideas sobre el matrimonio y la esposa en sus versos, ¿podría considerarse que la visión del poeta barcelonés nace solo de su propia experiencia o puede ser parte de la nueva sensibilidad hacia la mujer y la nueva concepción ideológica del matrimonio que desarrollan algunos humanistas? Las dos fuentes didáctico-morales que más claramente podemos relacionar con la visión de la mujer, de la esposa y del matrimonio presentes en la epístola a Mendoza, teniendo también en cuenta su cercanía cronológica con respecto a las obras a Boscán, son la Institutione faeminae Christianae (1524) del humanista valenciano Juan Luis Vives (1492-1540), escrita cinco ańos después del Elogio del matrimonio de Erasmo, que impulsa esta corriente de pensamiento, y El cortesano (1528) del mantuano Baldassar Castiglione (1478-1529), cuya influencia en Boscán está fuera de toda duda.

La obra de Vives pudo constituir un marco teórico que sustentara la visión positiva de Boscán acerca del matrimonio y el panegírico de la convivencia que aparece en la epístola, en la que la mujer no se presenta solo como objeto del amor y deseo, sino sobre todo como compañera: con ella disfruta la vida social de la ciudad y la vida tranquila del campo, con ella pasea, lee poesía clásica amorosa y épica y discute sobre ella, degusta los placeres de la comida y la conversación. Aunque Vives incide más en la función del matrimonio para asegurar la descendencia que Boscán, que solo le dedica a esta idea los versos, «la mesa de muchachos rodeada,/ muchachos que nos hagan ser agüelos ${ }^{57}$, comparten, frente a otros pensadores, el desarrollo de otras ventajas de tener esposa, especialmente la convivencia. Así defiende esta idea Vives:

57. Boscán (1999): 367. Llama la atención que Pontano (2006): 35 también hablaba de sus nietos en el poema 12 «Uxorem ac liberos invitat at diem natalem celebrandum", aunque en ese caso como una realidad, y con muchos más detalles. 
Diremos primero, que los siete Sabios de Grecia estuvieron todos casados; también se casaron Pitágoras, Sócrates, Aristóteles, Teofrasto, los Catones, Cicerón y Séneca, seguramente porque vieron que nada estaba tan en concordancia con la naturaleza como la unión de un hombre y de una mujer, gracias a la cual el género humano, que es mortal en cada uno de sus miembros, en su totalidad se perpetúa, y devuelves a tus descendientes lo que recibiste de tus ascendientes, como si le dieras las gracias a la naturaleza. Aristóteles aconseja en sus libros morales que el ciudadano tome esposa no solo por causa de los hijos sino también por la convivencia, pues ésta es la primera y la mayor de las uniones. ${ }^{58}$

También se pueden relacionar las virtudes que Boscán encuentra en el matrimonio con la imagen del matrimonio ideal que aparece en Vives. El poeta no insiste, como el humanista, en la necesidad de que la esposa sea casta y le ame, aunque parece que dichos requisitos se dan por sobreentendidos. Ambos coinciden en la importancia de la amistad dentro del matrimonio, idea platónica que Vives, con su avanzada concepción de la psicología humana, desarrolla como la fusión no solo de las almas y los cuerpos, sino de las personas:

Entre las virtudes propias de la mujer casada, conviene que tenga dos de máxima importancia y que sobresalen por encima de las demás. Si esas dos estuvieran presentes, pueden convertirse los matrimonios en algo firme, estable, duradero, fácil, soportable, dulce y agradable [...] Estas virtudes son la castidad y un gran amor al marido. ${ }^{59}$

Y si la amistad que parte de dos almas las convierte en una unidad, ¿cuánto más verdadera y eficazmente conviene que esto se garantice con el matrimonio, siendo como es lo único que aventaja, con mucho, a todas las demás amistades? Por esta razón se dice que forman no solo un alma o un cuerpo partiendo de dos, sino también una sola persona. ${ }^{60}$

Una de las características que más sorprenden de la esposa descrita por Boscán en su epístola es su cultura, y su interés por la poesía clásica amorosa y épica, de autores que en su mayoría solo podría leer o escuchar en latín o en la traducción oral del marido. Como ha señalado Álvaro Alonso ${ }^{61}$, «muchos moralistas, en su deseo de combinar lo útil y lo dulce, proponían a la mujer la lectura de textos exclusivamente religiosos: así, por ejemplo, en el capítulo III del De officio mariti, Vives aconseja al esposo que proporcione a su mujer poemas de Prudencio o Sedulio, en el caso de que ella sea aficionada a los versos». Parece, por tanto, que las lecturas de Boscán y su mujer no coincidirían con las recomendadas por Vives. Pero en la Institutio aparece otra idea que sí podría ser la que ilustra Boscán: la necesidad de que la esposa se interese por los asuntos del marido. Y siendo el marido poeta principalmente amoroso, ¿cómo no va a leer, y por tanto, compartir con su mujer,

58. Vives (1994): 197.

60. Vives (1994): 213.

59. Vives (1994): 205.

61. Alonso Miguel (2008): 2791-2800. 
la poesía de Propercio y Catulo, aunque no fueran considerados apropiados desde un punto de vista moral? La conexión de Boscán con esta idea se refuerza por el hecho de que una de las autoridades a las que recurre Vives para sustentar su recomendación es, precisamente, Horacio, en su epístola I, $18^{62}$, aunque el humanista traslada la anécdota de la esfera de la amicitia a la del matrimonio. Esto es una muestra de cómo las ideas éticas de Horacio, expresadas con mayor claridad en sus epístolas, se leen y adaptan a la mentalidad renacentista. Advierte Vives:

También resultará provechoso para la mujer casada recordar aquel consejo que Horacio, poeta prudente, dio a Lolio sobre un amigo, para que se habituara a las costumbres y quehaceres del mismo: «Si él quisiera ir a cazar, no te dediques tú a componer poemas, sino que, dejando de lado las Musas, sigue a las acémilas cargadas de redes y a los perros» [...] Cecilio Plinio declara en muchas cartas suyas que únicamente amó a su mujer y entre esas cartas hay una dirigida a Híspula, tía de su mujer y que la había educado a ella. En esa carta no solo le da las gracias por haberle dado a la muchacha una formación tan esmerada sino también le descubre el motivo por el que amaba tan entrańablemente a su esposa, expresándose sobre ella de la siguiente manera: «Me ama, algo que es indicio de castidad; hay que añadir a esto su afición a las letras, afición que surgió precisamente del amor que me profesaba. Maneja mis libritos, los lee y relee e incluso los aprende de memoria ${ }^{63}$.

Así se incorpora a Ana Girón de Rebolledo a la galería de esposas ilustres que ayudaron a sus poetas artistas y compartieron sus intereses, como Híspula con Plinio o Pola Argentaria con Lucano. Este último caso, que también recoge Vives en su tratado, es especialmente significativo porque, según la tradición, la viuda terminó $L a$ Farsalia tras la muerte de su marido, y no hay que olvidar que la participación de la esposa de Boscán en sus labores poéticas llega a su culmen cuando, ya viuda, se encarga de la edición de sus poemas y los de Garcilaso, si bien la dimensión de su participación aún está por determinar.

Otro punto de contacto entre las ideas de Vives y la epístola de Boscán es la imagen de la función de la esposa como apoyo del marido, y su capacidad para entretenerle, adoctrinarle en el buen camino, animarle o aplacarle, y sobre todo conducirle hacia la virtud. El efecto positivo de la mujer coincide completamente con el descrito por el poeta, ya que ella logra que su marido alcance el término medio aristotélico, y le ayuda a controlar las pasiones. El siguiente pasaje, por tanto, sí parece haber influido directamente en Boscán:

La mujer prudente sabrá de memoria leyendas, historietas y cuentos cortos, tan divertidos como, por supuesto, honestos y puros, con los que reponer y divertir a su marido cuando esté cansado o enfermo; deberá conocer igualmente los preceptos de la sabiduría, adecuados para inducirle a la virtud o alejarle de los vicios; asimismo, algunos pensamientos profundos que le sirvan contra los ataques de la buena y 
mala fortuna y le hagan volver a la realidad, poco a poco, si se ha dejado llevar por la euforia, o le levanten el ánimo si se halla abatido o derrotado por las adversidades. $\mathrm{Y}$, tanto de uno como de otro extremo, retorne al término medio. Si se apoderan de él y se alborotan algunas pasiones, la mujer mitigará y aliviará esa tempestad con lenitivos femeninos, castos y prudentes. ${ }^{64}$

Es muy llamativa la coincidencia en la idea de que la mujer logra que el marido retorne al término medio, así como la capacidad de la esposa de «aliviar» al marido, dado que los «lenitivos femeninos, castos y prudentes» son, sin duda, referencias claras a las que Boscán también alude, con la misma insistencia en el adjetivo "casto».

Además de la exaltación de la convivencia y la amistad conyugales, y de los atributos intelectuales y habilidades psicológicas de la esposa, Boscán señala a su vez, como Vives, —basándose en San Pablo — la función práctica de la mujer como administradora de la hacienda común, previa defensa del carácter positivo del dinero. Le dedica a ello nueve tercetos (vv. 184-210), tres de los cuales son especialmente significativos: «Otras vezes también, pienso algún’ ora,/las cosas de mi hazienda sin codicia/aunque 'sta comúnmente es la señora», «Solo quiero escusar tristes pobrezas,/por no sufrir sobervias d'hombres vanos/ni de ricos estrechos, estrechezas./Quiero tener dineros en mis manos,/tener para tener contenta vida/ con los hidalgos y con los villanos»" ${ }^{65}$. Así defendía Vives la misma idea:

Porque, ¿acaso no es una locura considerar el dinero como un mal, siendo como es algo tan liviano y lo último entre aquellas cosas que suelen elevar el espíritu de los hombres? Pero a muchos les ocurre que sus espíritus inconstantes y vacíos se hinchan por una suave brisa. Insensata, ¿acaso el matrimonio no lo hace todo común? Si gracias a la amistad todas las cosas se hacen comunes, ¿cuánto más comunes no se volverán con el matrimonio? Y no solo el dinero sino también los amigos, los parientes y todas las cosas. Como dice Plutarco, «igual que lo expresaron los romanos en sus leyes, en las que se prohibía que se diera o se aceptara algo entre los cónyuges para que no pareciera que hubiese algo distinto o fuese propiedad de cada uno de ellos». En la mejor república, como enseña Platón, "Conviene que se quite 'lo mio' y 'lo tuyo' ¡Cuánto más debería darse en el mejor de los hogares, que solo entonces es el mejor, el más perfecto y por este motivo el más feliz, cuando, bajo una cabeza única, solo existe un único cuerpo! Porque si tuviera varias cabezas o varios cuerpos sería un monstruo. ${ }^{66}$ San Pablo ańade la preocupación por la hacienda familiar a la prudencia y a la castidad de las mujeres. ${ }^{67}$

Boscán comparte además la importancia que otorga Vives en este mismo pasaje a compartir todo y a pensar con una sola cabeza dentro del matrimonio. Esta concepción del matrimonio se advierte en el empleo del plural para todas las actividades que el poeta describe de su vida idealizada: «comamos y devamos», "passaremos», "quando pesada la ciudad nos sea, iremos [...]», «no-

64. Vives (1994): 261.

66. Vives (1994): 250.

65. Boscán (1999): 366-367.

67. Vives (1994): 301. 
sotros seguiremos sus pisadas», "nos andaremos», «nos sentaremos», "nosotros correremos», "no ternemos embidia», "ternemos nuestros libros», "veremos», «oyremos», nosotros nos iremos passeando», "veremos platicando", «avremos reposado", "ayamos bien comido", "passaremos la noche dulcemente» ${ }^{68}$, etc. Lo que importa es que marido y mujer no solo coinciden en sus gustos y apetencias, sino también en sus ideas y pensamientos, es decir, se escenifica perfectamente la concordancia de cuerpos, almas y personas que defendía Vives; la imagen del matrimonio como una república con una sola directriz: el bien común.

Las dos últimas ideas comunes en Vives y Boscán se refieren a la imagen de las relaciones entre los esposos. El «lecho de paz durable» que el poeta oponía al "campo de batalla ${ }^{69}$ del enamorado no correspondido, también puede oponerse a las malas relaciones conyugales, que pueden suponer otro campo de batalla más. Vives, basándose en Plutarco ${ }^{70}$, defiende la importancia del sexo en la pareja como una medicina y un instrumento de reconciliación, idea que sin duda aparece en la epístola:

También dice Plutarco que no se debe discutir en el lecho conyugal, pues, ¿̨ónde van a deponer las heridas infringidas a sus almas, si el lugar más apropiado para la reconciliación lo han vuelto, con sus altercados, aborrecible y odioso y, por decirlo de algún modo, han desperdiciado la medicina más apropiada para curar las enfermedades de sus almas? ${ }^{? 1}$

Por último, el humanista y el poeta comparten la defensa de la privacidad y la intimidad dentro del matrimonio, aunque Vives señala la importancia del secreto refiriéndose a la mujer, y Boscán aplica este precepto a sí mismo, e insiste no tanto en la dimensión moral como en la poética: no quiere escribir poesía vana - se entiende, erótica o burlesca - por lo que no va a dedicar sus versos a describir con detalle las relaciones sexuales con su mujer. Defiende Vives:

Procure una y mil veces la esposa que, todo aquello que se dice o se hace en el aposento o en el sacrosanto lecho matrimonial, sea considerado secreto inviolable y debe guardarse incluso con más silencio del que, antiguamente se guardaba en Eleusis con los ritos de la diosa Ceres o, si queremos decirlo más correcta y adecuadamente, como las cosas que al oído del confesor le cuenta quien se confiesa. ¿Qué clase de locura, es divulgar cosas que deben callarse y silenciarse con tanto cuidado? $^{72}$

El mayor punto de divergencia entre el pensamiento teórico de Vives sobre el matrimonio y la descripción de Boscán de su aplicación práctica es, jun-

68. Boscán (1999): 367-372.

69. Boscán (1999): 365.

70. Las ideas de Plutarco sobre el matrimonio fueron una de las fuentes clásicas más importantes para la creación de una imagen positiva del mismo. En 1535 sus Praecepta connubialia fueron traducidos por Jehan Lode en París, lo que puede justificar una mayor difusión.

71. Vives (1994): 256.

72. Vives (1994): 265. 
to a la recomendación de distintas lecturas para la mujer, la valoración de la pasión dentro de la pareja. Ambos elementos están muy relacionados, porque para Vives los poetas elegíacos debían de rechazarse por inmorales (idea compartida, como recuerda Álvaro Alonso ${ }^{73}$, por autores anteriores, como Pío II, y posteriores, como Mariana) sin duda por la expresión explícita de sus deseos y encuentros sexuales, y son estos mismos elementos los que defiende que deben rechazarse en el matrimonio. Boscán, por tanto, parece contravenir al mismo tiempo dos normas, una literario-moral (leer poesía amorosa con su mujer) y otra moral-conductual (desear a su mujer y disfrutar con ella), alejándose de preceptistas morales como Vives, aunque sin llegar al atrevimiento de poetas neolatinos como Pontano. El humanista valenciano defendía:

Conviene que los varones no anden sumergidos en placeres desmedidos, ni se diviertan con otras mujeres diferentes a sus esposas. Pero aquí no adoctrinamos a los maridos, a pesar de que este lugar debería dirigirse más bien a ellos con objeto de que no se erigieran en maestros de placeres y lascivia para sus esposas y recordaran aquel breve pensamiento del pitagórico Xisto: «Comete adulterio con su mujer todo el que ama a su mujer impúdicamente y con demasiado ardor»; y a su vez obedecieran al apóstol San Pablo, quien recomienda a los maridos «que posean con satisfacción a sus mujeres como si se tratara de vasos de generación y no sumidos entre pasiones desmesuradas e ilícitas, como hacen los gentiles que desconocen a Dioss ${ }^{74}$

Pese a esta diferencia en cuanto a la concepción del sexo dentro del matrimonio, donde Boscán acentúa más la importancia del placer («holgarse») que de la función reproductiva, parece que en general las ideas del erasmista Vives sí pudieron constituir para el poeta un apoyo en su defensa del amor matrimonial. Es difícil precisar si las semejanzas entre los textos de Vives y Boscán obedecen a una influencia directa porque muchas de las ideas coincidentes se formulan de modo similar en otras obras. Pero si cada uno de los paralelismos no sería probatorio en sí mismo, la acumulación de los mismos permite apuntar a una relación directa.

En cuanto a la posible relación de la ideología de Il cortegiano de Castiglione sobre la mujer y el matrimonio con la epístola, en el Libro II del tratado que tradujo Boscán también se configura la imagen de una esposa que sabe gobernar la hacienda del marido, además de la casa y los hijos. El personaje de Julián el Magnífico, en su retrato de la mujer ideal, advierte que las damas de la corte deben tener "conversación dulce y graciosa y conforme al tiempo, lugar y calidad de con quien hablare» y que "es necesario que la dama [...] tenga noticia de muchas cosas [...] conversación larga, agradable y sustancial ${ }^{75}$. Reconoce la dificultad de que la mujer llegue al término medio que se le exige en el trato con los hombres: «tiene necesidad de guardar una cierta medianía difícil y casi

73. Alonso Miguel (2008).

74. Vives (1994): 266.
75. Castiglione(1946):97.Reproduzcolatraducción del italiano al castellano del propio Boscán. 
compuesta de contrarios, con la cual llegue puntualmente a cierto término con tan buen tiento que no le pase» ${ }^{76}$. Es decir, en lugar de destacar la función de la mujer para ayudar al hombre a alcanzar el término medio, se reconoce lo difícil que es para ella llegar a esta moral y conducta ideal que los hombres le exigen. También espera de ella las virtudes estoicas: continencia, grandeza de ánimo, templanza, fortaleza y prudencia. Del mismo modo, Julián el Magnífico defiende la inteligencia de las damas: «las mujeres, por ser más delicadas de carne, serán de entendimiento más sutil y de ingenio más hábil para la especulación que los hombres» ${ }^{77}$. Boscán coincide en términos generales con esta defensa de las capacidades de la mujer - también realizada en su carta a la Duquesa de Soma- y parece apreciar en ellas las mismas cualidades. Solo se aleja de la insistencia en la función procreadora del matrimonio que Julián el Magnífico destaca en términos casi exactos a los de Vives.

Atendiendo a los efectos de la mujer sobre el hombre, Boscán también coincide en la epístola con las ideas del personaje Julián, que sostiene que el hombre es de naturaleza caliente y por ello tiende al movimiento y la mudanza, mientras que la mujer, al ser de naturaleza fría, tiende al sosiego, la gravedad y firmeza, de ahí su capacidad para templar al hombre ${ }^{78}$. Julián también defiende el efecto positivo de la esposa frente a quienes recuerdan a Eva: «algunas mujeres han sido causa de infinitos bienes a sus maridos, y a hartos dellos han corregido muchos yerros ${ }^{79}$. Pero la visión de Boscán parece coincidir todavía más con la del personaje Micer César, que en un encendido monólogo también defiende los efectos positivos de las mujeres, especialmente psicológicos y morales:

¿Quién no sabe que sin mujeres no se puede alcanzar placer ni contentamiento en esta vida; la cual sin ellas sería grosera, sin ningún gusto y casi salvaje, y más áspera que la de las fieras alimañas? ¿Quién no alcanza que las mujeres son las que quitan en nuestros corazones todos los bajos y viles pensamientos, las fatigas, las miserias y aquellas tristezas tristes que andan en compañía de todo esto ${ }^{\text {?0 }}$ Acerca del conocimiento de las cosas grandes no nos desvían ellas, ni nos embarazan, antes nos despiertan y nos levantan [...] Yo tengo por imposible que en corazón de un hombre donde una vez haya entrado amor pueda jamás entrar vileza o cobardía; porque quien ama desea siempre hacer cosas que le hagan ser amado. ${ }^{81}$

Boscán también parece compartir las ideas que expresa el mismo personaje en cuanto a la importancia de la mujer como musa de los poetas en lengua vernácula, y la visión del amor matrimonial como lo más cercano al amor divino:

¿Quién compone buenos versos a lo menos en lengua vulgar, sino por declarar aquellos sentimientos que los enamorados padecen por causa de ellas [...] Acor-

76. Castiglione (1946): 97.

77. Castiglione (1946): 105.

78. Castiglione (1946): 107.
79. Castiglione (1946): 113.

80. Castiglione (1946): 146.

81. Castiglione (1946): 147. 
dáos de cuantas cosas maravillosamente escritas en la poesía careceríamos agora en la lengua griega y en la latina, si las mujeres no hubieran sido tenidas en mucho por los poetas [...] Acordaos de Salomon, que queriendo escribir cubiertamente cosas altísimas y divinas fingió, por ascondellas debajo de un hermoso velo, un blando y ardiente diálogo de un enamorado con su amiga, pareciéndole que no se podía hallar aquí entre nosotros semejanza más conforme a las cosas divinas que el amor de un singular hombre con una singular mujer ${ }^{82}$

La cuestión en la que sin duda podemos encontrar más paralelismos es la del sexo dentro del matrimonio, pues El Magnífico insiste en la importancia de las buenas relaciones sexuales para evitar adulterios — que no condena si no se dan estas buenas relaciones_-, empleando la misma imagen que Vives de la cama como lugar de concordia, que Boscán retomará. El personaje de El cortesano emplea el contraejemplo de las «malmaridadas» para destacar la importancia de su idea:

en la cama, la cual debería ser lugar de concordia y de amor, siembra la maldita furia infernal del diablo su ponzoña, de la cual después nacen las rencillas, las sospechas y las espinas del triste aborrecimiento que atormentan aquellas cuitadas almas atadas cruelmente con la recia cadena que quebrar no se puede hasta la muerte, ¿̨por qué no consentiréis vos que a esta mujer que está en tan duro estado, le sea permitido buscar algún alivio para tantos trabajos, y dar a otro aquello que del marido es no solamente despreciado, más aun aborrecido? ${ }^{23}$

También podría haber influido a Boscán en su comparación del amor singular y correspondido y los amores múltiples y débiles la metáfora empleada por el personaje Emilia, que destaca la importancia de concentrarse en un amor: «los ríos repartidos en muchas partes, viene a traer poca agua; así también el amor que se reparte, viene a tener poca fuerza ${ }^{84}$. Compárese con los tercetos:

En mí las otras yvan y venían, $\mathrm{y}$ a poder de mudanças a montones de mi puro dolor se mantenían. Eran ya para mí sus gualardones, como thesoros por encantamientos, que luego se bolvían en carbones.

Agora son los bienes que en mí siento, firmes, maciços, con verdad fundados, y sabrosos en todo el sentimiento ${ }^{85}$ (vv. 136-144)

El rechazo de Boscán de sus pasados amoríos parece relacionarse además con lo que describe en el Libro IV el personaje que representa a Bembo acerca 
de los hombres que, movidos por el apetito del sentido, y no por la elección de la razón, creen gozar de la hermosura poseyendo el cuerpo en el que mora, y obtienen un placer falso, por lo que o bien quedan hartos, aborrecidos y arrepentidos, o bien con el mismo deseo, porque no han alcanzado lo que buscaban:

puesto que por la ciega opinión, que los tiene borrachos, les parezca que en aquel punto sientan placer, como acaece a los enfermos que sueñan beber en alguna fuente clara, no por eso se contentan ni quedan sosegados [...] con la misma fatiga que primero sentían, se hallan en mitad de la brava y ardiente sed de aquello que en vano esperan poseer perfectamente. ${ }^{86}$

Esto lleva a tener el «alma presa y aherrojada en la prisión de la carne», pues «va mendigando de los sentidos para conocer las cosas». Así, Boscán habría iniciado el camino marcado por Bembo, desde los amores sensuales de la juventud hasta el amor más elevado de la madurez, pero sin llegar a la contemplación divina, que al menos en la epístola no aparece. Quizá Boscán rechazara la vía neoplatónica porque pensaba, como el personaje de Micer César: «el camino [...] de esa tan alta bienaventuranza me parece tan áspero, que realmente yo tengo por cosa muy difícil podelle andar» ${ }^{87}$.

\section{Conclusiones}

Del análisis de la epístola de Boscán se desprende que el amor conyugal es el eje central de la filosofía práctica del poema. El amor matrimonial se relaciona con el resto de elementos de la vida ideal de forma jerárquica, siendo el requisito imprescindible para alcanzar la felicidad, como sinónimo de la «dorada medianía». La vida retirada en el campo o la vida social de la ciudad son dependientes del matrimonio, en tanto que responden a sus deseos cambiantes. El ideal de tener suficiente dinero y los placeres de la comida y la lectura también están sujetos a la esposa, puesto que todo se comparte con ella.

Este protagonismo del matrimonio y de la mujer justifica el haber centrado este estudio en ambos temas, ya que sin comprender cómo los aborda Boscán no puede comprenderse e interpretarse correctamente la epístola. Podemos concluir que el matrimonio se concibe como una fuente de felicidad y de enriquecimiento moral, al convertirse en el vehículo del «término medio» que conlleva la estabilidad psicológica y material. Según las ideas que aparecen en la epístola, la esposa permite alcanzar el ideal de la moderación, ya que con ella pueden culminarse los deseos sexuales sin que haya perjuicios morales o condenas religiosas. Además, gracias a ella el estado anímico del enamorado petrarquista, atormentado por la no correspondencia de sus sentimientos y por la insaciabilidad de sus deseos, da paso a un estado de sosiego, calma y satisfacción. Desde un ángulo meta-poético, 
la esposa abre las puertas a una renovación del tratamiento poético del amor, y a una superación de la faceta amorosa del petrarquismo, ya que inicia el canto del amor correspondido, social y moralmente encomiable; en definitiva, abre paso a una poesía que no puede ser condenada por los moralistas sino que debe de ser comprendida como un cancionero de salmos «a lo profano».

La comparación de la poesía matrimonial de Boscán con la de su precursor neolatino Pontano nos muestra que ambos comparten la alabanza a los efectos rejuvenecedores del amor correspondido en el hombre ya maduro, si bien el italiano insiste más en la belleza de la mujer y el barcelonés en sus cualidades psicológicas e intelectuales, así como en sus efectos beneficiosos en el marido. Pontano, además, es más explícito en cuanto a la expresión del sexo y la pasión dentro del matrimonio, pero eso no resta valor al peso que Boscán otorga a este aspecto y que es buena muestra de su intento de renovación a través del tratamiento del amor en su poesía, ya que esta dimensión sensual del amor no es tan frecuente en la lírica amorosa no erótica, que, después de Boscán, tampoco tiene demasiados representantes aparte de Francisco de Aldana-. En cuanto a la conexión con Jean Salmon Macrin, el «nuevo canto» de Boscán cobra mayor relevancia cuando se advierte que incluso en poemas de amor matrimonial como los del poeta neolatino francés, la impronta del petrarquismo se mantenía, y se describía el amor por la esposa como un fuego de efectos devastadores tanto desde el punto de vista moral como psicológico. Solo la oda de Salmon dirigida directamente a la esposa presenta semejanzas con el intercambio epistolar entre Boscán y Hurtado de Mendoza, entre las que destacan la idea del retiro en el campo junto a la amada y la fantasía de los besos apasionados y las flores que ella le daría. Mientras que la relación directa entre Salmon y los poetas españoles no se puede demostrar por el momento, sí está más clara la influencia de Boscán sobre el portugués António Ferreira, cuyo ciclo de sonetos de «nuevo amor» y cuya descripción del retiro en el campo con la amada en un pasaje epistolar presentan paralelismos con los sonetos del barcelonés y su epístola a Hurtado de Mendoza que no pueden resultar casuales, conexión que se ve reforzada por las fechas, la difusión de Boscán en Portugal y las coincidencias verbales e ideológicas.

En último lugar, la construcción ideológica del matrimonio y la visión de la esposa que aparece en la epístola de Boscán presentan importantes concomitancias con las ideas que encontramos en los tratados de Juan Luis Vives y de Castiglione. Boscán parece tener en cuenta el pensamiento de Vives sobre la necesidad de la amistad y la afinidad personal en el matrimonio, sobre la conveniencia de que la esposa se interese y participe en los asuntos del marido - en este caso, la poesía-, y de que ayude asimismo en la administración de la hacienda familiar. Se aleja del humanista en cuanto a la poca insistencia en la procreación y el énfasis puesto en la pasión dentro del matrimonio. De los personajes de los diálogos de Castiglione, especialmente de don Julián y de Micer César, parece haber aprendido Boscán gran parte de su discurso a favor de la mujer, además de compartir la idea de la poderosa y positiva influencia de la esposa sobre el 
comportamiento y la actitud psicológica del marido, y de los efectos saludables del deseo sexual dentro del matrimonio, ya que Boscán no concibe la unión con su mujer en términos neoplatónicos, sino que insiste ante el soltero Hurtado de Mendoza - a juzgar por sus cartas en prosa $^{88}$, pese a sus numerosas amantes, frustrado por no lograr casarse- en que el matrimonio también es la mejor solución a tales conflictos. Tanto Vives como Castiglione, pues, ofrecen a Boscán un esqueleto argumental en el que apoyarse para su exaltación de la esposa, del matrimonio y de sus efectos saludables en el hombre.

88. Hurtado de Mendoza (1935). 


\section{Bibliografía}

Alonso Miguel, Álvaro, «Mujer y lectura en el Renacimiento: el canon clásico de Boscán", Humanismo y pervivencia del mundo clásico: homenaje al profesor Antonio Prieto. IV, José María Maestre Maestre, Joaquín Pascual Barea, Luis Charlo Brea, Vol. 1, Madrid, Consejo Superior de Investigaciones Científicas, 2008.

Boscán, Juan, Las obras de Juan Boscán, Carlos Clavería, Promociones y Publicaciones Universitarias, Barcelona, 1991.

—, Obra completa, Carlos Clavería, Madrid, Cátedra, 1999.

Castiglione, Baltasar, El Cortesano, traducción de Juan Boscán, Buenos Aires y México, Espasa-Calpe Argentina, 1946.

Catálogo Colectivo del Patrimonio Bibliográfico Español, 10-06-2013, http:// www.mcu.es/bibliotecas/MC/CCPB/index.html.

Clavería, Carlos, «Introducción» y notas a Boscán, Juan, Obra completa, Madrid, Cátedra, 1999.

Earle, Thomas F., introducción y notas a Ferreira, António, Poemas lusitanos, Lisboa, Fundación Calouste Gulbenkian, 2008.

-, The muse reborn. The poetry of António Ferreira, Oxford, Clarendon Press, 1988.

—, «A Portuguese Sonnet Sequence of the Sixteenth Century», Bulletin of Hispanic Studies, 63 (1986) 225-234.

EDIT 16, Censimento nazionale delle edizioni italiane del XVI secolo, 10-06-2013, http://edit16.iccu.sbn.it/web_iccu/ihome.htm.

Ferreira, António, Poemas lusitanos, Thomas F. Earle, Lisboa, Fundación Calouste Gulbenkian, 2008.

Gil de Biedma, Jaime, Las personas del verbo, Barcelona, Círculo de Lectores/ Galaxia Gutenberg, 2006.

Hurtado de Mendoza, D., Poesía completa, Ignacio Díez Fernández, Sevilla, Fundación José Manuel Lara, 2007.

—, Algunas cartas de Diego Hurtado de Mendoza. 1538-52, A.Vázquez y R. Selden, Yale University Press, 1935.

Petrarca, Francesco, Canzoniere, Madrid, Cátedra, 2008.

Pontano, Giovanni Giovano, Baiae, traducción del latín al inglés de Rodney Dennis, Cambridge (Massachusetts)/ Londres, Harvard University Press, 2006.

Quinto Horacio Flaco, Epistolas y Arte poética, traducción de Fernando Navarro Antolín, Madrid, CSIC, 2002.

ReEser, Todd W., «Moderation and masculinity in Renaissance Marriage Discourse and in Rabelais's Tiers livre», en Romanic Review, 90 (1999), 1-26.

SALmon, Jean, (Macrin), Épithalames et Odes, traducción del latín al francés de Georges Soubeille, París, Honoré Champion, 1998.

SANDIDGE, Marilyn, "Constructing New Women in Early Modern English Lite- 
rature", Discourses of Love, Marriage and Transgression in Medieval and Early Modern Literature, Albert Classen, Arizona State University, 2004.

Tansillo, Luigi, Canzoniere, Biblioteca Italiana, Roma, Universidad de RomaLa Sapienza, 2003, 10-05-2012, http://www.bibliotecaitaliana.it

Vega, Garcilaso de la, Poesias castellanas completas, Madrid, Castalia, 1996.

VIVES, Juan Luis, La formación de la mujer cristiana (De institutione feminae christianae), traducción del latín al castellano de Joaquín Beltrán Serra, Valencia, Ayuntamiento de Valencia, 1994, Biblioteca Valenciana Digital, 12-2009, http://bivaldi.gva.es/i18n/corpus/unidad. cmd?idUnidad $=10066 \&$ idCorpus $=1$

Weich, Horst, «La polifonía del discurso amoroso en Juan Boscán: La Canción LII 'Gentil señora mía'”, Actas del V Congreso Internacional de la Asociación Internacional Siglo de Oro. (AISO), Münster 20-24 de julio de 1999, Christoph Strosetzki, Madrid/ Frankfurt, Iberoamericana/ Vervuert, 2001. 